This item was submitted to Loughborough's Research Repository by the author.

Items in Figshare are protected by copyright, with all rights reserved, unless otherwise indicated.

\title{
EU external representation post-Lisbon: the performance of EU diplomacy in Belarus, Moldova and Ukraine
}

PLEASE CITE THE PUBLISHED VERSION

https://doi.org/10.1163/1871191X-13010035

\section{PUBLISHER}

Brill - Nijhoff

VERSION

AM (Accepted Manuscript)

\section{PUBLISHER STATEMENT}

This paper was accepted for publication in the journal The Hague Journal of Diplomacy and the definitive published version is available at https://doi.org/10.1163/1871191X-13010035.

\section{LICENCE}

CC BY-NC-ND 4.0

\section{REPOSITORY RECORD}

Baltag, Dorina. 2018. "EU External Representation Post-lisbon: The Performance of EU Diplomacy in Belarus, Moldova and Ukraine”. Loughborough University. https://hdl.handle.net/2134/12941828.v1. 


\title{
EU External Representation Post-Lisbon: The Performance of EU Diplomacy in Belarus, Moldova and Ukraine
}

\author{
Dorina Baltag* \\ European Studies Programme, Department of Political Science, Maastricht University, Grote Gracht 90-92, \\ 6211 SZ Maastricht, The Netherlands \\ d.baltag@maastrichtuniversity.nl
}

\begin{abstract}
Summary
The European Union (EU) today has quasi-embassies at its disposal in third countries - the EU delegations - which represent the Union's eyes, ears and face. Following the Treaty of Lisbon, these delegations assumed the role of the rotating Presidencies and oversee the conduct of EU diplomatic affairs. In practice, this implies representing the EU and cooperating with EU member states' embassies on matters not only relevant for aid and trade, but also for foreign and security policy. By employing performance criteria such as effectiveness, relevance and capability, this article uncovers the particularities of the practices of European diplomatic cooperation among EU delegations and national embassies in Belarus, Moldova and Ukraine. Drawing on fieldwork conducted in Minsk, Chisinau and Kiev from 2013-2016, the article explores practices of European cooperation abroad, shows how EU diplomatic actors identify a common approach and emphasizes certain capability issues faced by the EU in these countries.
\end{abstract}

\section{Keywords}

EU delegations, EU member states' embassies, diplomatic cooperation, diplomatic performance, Moldova, Ukraine, Belarus.

\section{Introduction}

The aim for a stronger and more coherent European Union (EU) has been reinforced by the Lisbon Treaty with the introduction, inter alia, of the European External Action Service (EEAS). The creation of the EEAS and the upgrade to EU delegations on the ground can be seen as an innovation of the Treaty that is aimed at increasing the EU's visibility and raising its profile in international affairs. In third countries, the former Commission representations amount today to circa 131 bilateral EU delegations representing the EU. Similar to the EEAS, the EU delegations are staffed, in different departments, with a mixture of personnel from the EEAS, the European Commission, national diplomats, but also local employees. Like EU member states' embassies, EU delegations are tasked with traditional diplomatic functions: to represent the EU, as well as to explain and implement EU foreign policy. ${ }^{1}$

\footnotetext{
* This contribution is based on fieldwork conducted by the author between 2013 and 2016 as part of her on-going doctoral research within the framework of an Initial Training Framework, financed under the EU's 7th Research Framework Programme on Institutional Dynamics in the European Union (INCOOP, FP7-PEOPLE-ITN-2008). The author travelled to Belarus, Moldova and Ukraine and conducted semi-structured interviews with EU and national diplomats in EU member states' embassies and EU delegations.

${ }^{1}$ For more details, see Federica Bicchi and Heidi Maurer, 'European Cooperation Abroad: European Diplomatic Cooperation Outside EU Borders. Introduction to the Special Issue', The Hague Journal of Diplomacy, vol. 13, no. 1 (2018), pp. 1-19 this issue.
} 
The EEAS Review for $2013^{2}$ highlighted the enhanced partnership with the EU member states as

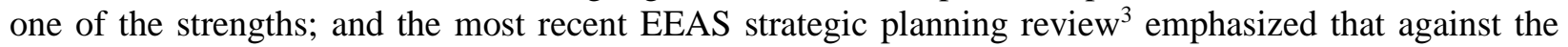
background of challenges in the EU's neighbourhood, EU diplomacy should seize the opportunity for cooperation between the national and EU levels in order to obtain a more effective collective effort. With a ring of instability that surrounds the EU from Eastern Europe to the Caucasus, the Middle East and the Horn of Africa, European diplomacy is in great demand and perennial questions regarding EU (diplomatic) performance arise. Following a 'practice turn' in EU studies, ${ }^{4}$ this article analyses fieldwork data collected ${ }^{5}$ between 2013 and 2016 in Belarus, Moldova and Ukraine to zoom in on the practices of EU diplomatic performance in Eastern Europe. Permanent developments in the EU's Eastern neighbourhood represent a challenging context for EU diplomatic 'actorness' and all three countries represent a test case for EU diplomatic performance and European cooperation abroad. This contribution reveals the cooperation practices between EU delegations and national embassies on the EU's immediate border, where EU ambitions are high. The case studies include the biggest and oldest established EU delegation in the neighbourhood (Ukraine: 1993) and the smallest and most recent (Moldova: 2005; and Belarus: 2008).

The analytical focus is not on the EU's diplomatic relationship with these countries per se, but rather on uncovering how the cooperation between the EU and its member states' diplomatic representations adds to the EU's aim of achieving a stronger, more efficient and coherent European Union foreign policy. The need for reform in diplomacy before the Lisbon Treaty related to the coexistence of EU and EU member states' diplomacy with parallel, rather than coherently intertwined, direction: issues related to institutional competences and diplomatic representation abroad; institutional as well as national and EUlevel power struggles; and general confusion regarding leadership in diplomatic activity on the ground, ${ }^{6}$ just to name a few. The Lisbon Treaty introduced a number of changes to EU diplomacy in Brussels and on the ground ${ }^{7}$ : the EU acquired legal personality; the EU delegations were integrated into the newly established EEAS; and the EU delegations assumed the functions of the rotating Presidency, and were thus tasked with coordinating with national diplomatic representations of EU member states abroad. ${ }^{8}$ By using the performance criteria of effectiveness, relevance and capabilities, this study addresses the criticisms that were raised before the Lisbon Treaty regarding European diplomatic cooperation, including lack of leadership, questions concerning representation, and hence the issue of continuity and coherence between the EU and EU member states in third countries.

The article proceeds as follows. The analytical framework couples performance criteria with key concepts from EU diplomatic practice. The empirical data is analysed in the four subsequent sections, which show how the EU delegations are performing the traditional diplomatic tasks of representation and communication, while conducting aid-driven diplomacy (a legacy from the former Commission representations) and embracing the new tasks of cooperation with the EU member states. The analysis also shows that when it comes to capabilities, a screening of resources emphasizes two main issues - human resources and intra-institutional conflicts - that hamper coherent EU action.

\footnotetext{
${ }^{2}$ For the full text of the EEAS Review, see online at https://eeas.europa.eu/library/publications/2013/3/2013_eeas_review_en.pdf.

3 EEAS, 'The European Union in a Changing Global Environment' (Brussels: EEAS, 2015), available online at https://europa.eu/globalstrategy/en/strategic-review-european-union-changing-global-environment.

${ }^{4}$ Rebecca Adler-Niessen, 'Towards a Practice Turn in EU Studies: The Everyday of European Integration', Journal of Common Market Studies, vol. 54, no 1 (2016), pp. 87-103; and Emanuel Adler and Vincent Pouliot, 'International Practices', International Theory, vol. 3, no. 1 (2011), pp. 1-36.

${ }^{5}$ The author conducted 48 in-depth semi-structured interviews with twelve EU (of which seven EEAS and five Commission) and 34 national diplomats (and also two local staff members). All interviews followed a guide, lasted 60 minutes on average, and have been codified and anonymized.

${ }^{6}$ Dorina Baltag and Michael Smith, 'EU and Member State Diplomacies in Moldova and Ukraine: Examining EU Diplomatic Performance Post-Lisbon', European Integration online Papers (EIoP), vol. 19 (2015), pp. 1-25.

${ }^{7}$ for more details, see Bicchi and Maurer, 'European Cooperation Abroad. Introduction to the Special Issue'.

${ }^{8}$ See Treaty on European Union (TEU), article 4.3.
} 


\section{Performance: A Three-Dimensional Lens to Analyse Diplomacy and European Cooperation Abroad}

When talking about European cooperation abroad, ${ }^{9}$ the focus is on practices and the management of relations between two actors. This contribution links the debates regarding European cooperation abroad and EU diplomatic practice with the discussion on performance in order to uncover the nature of these practices. Organizational performance focuses on practice as the unit of analysis in order to evaluate that is, to understand the clarity of the objectives and the vision of an actor. This allows us to understand the direction of the implementation of these objectives and to reflect on how much progress has been made towards the goals. A performance exercise to the same extent entails learning about what is working and what is not. This ultimately may lead to improving, which comes with the capacity to adopt and adapt, as a performance exercise explores the variety of organizational practices. ${ }^{10}$ Therefore, the analytical purpose here is not to study the cause-effect relationship, but rather the dimensions of everyday diplomatic practices in third countries: 'how things are supposed to be, and the political universe of how they very often actually are'. ${ }^{11}$ In this article, looking at performance implies examining and evaluating EU diplomatic practices against pre-set goals. It also allows us to learn about the relationship between the national and EU levels in the new post-Lisbon setting, where the EU delegations perform traditional and new diplomatic functions: representing the European Union; but also cooperating with national embassies. Finally, it allows us to conduct a screening of capabilities and to understand how these pertain to the diplomatic realm. To do so, this article adapts the operationalization offered by organization performance literature ${ }^{12}$ and proposes measuring performance in relation to effectiveness, relevance and capabilities.

Effectiveness is defined by the extent to which an organization is able to fulfil its goals. ${ }^{13}$ It is a challenging task to evaluate EU goal achievement in foreign policy and diplomacy. For political systems, it is often a challenge to identify the goals, especially those that are not stated explicitly. In discussing the dimensions of effectiveness as a goal achievement, research also places emphasis on the fact that 'objectives can be so broad as to render them nearly meaningless for an assessment' ${ }^{14}$ However, goals are identified in the Lisbon Treaty, which tasks the EU delegations with 'representing the Union' ${ }^{15}$ Representation is one of the core traditional functions of diplomacy and it looks into how an actor represents itself to others and consists of a formal and substantial dimension. ${ }^{16}$ Formal representation refers to the diplomatic protocol and participation in official events, while the substantive dimension refers to explaining and defending national policies as well as interpreting those of the other actor. Diplomacy, as representation, is hence not limited to protocol, but is conscious of both the practice and the context. ${ }^{17}$ Exploring this idea implies unveiling how the post-Lisbon diplomatic system manages the problem of continuity in EU diplomacy. ${ }^{18}$ Achieving the goal of representing the Union in third countries, by replacing the rotating Presidency in political affairs, should also address the issue of visibility and reduce diplomatic complexity - that is, national diplomats represent their states, while the EU delegation represents the European Union.

\footnotetext{
${ }^{9}$ The focus here is on cooperation and not coordination, as the analysis is interested in the daily interaction and the set of activities that constitute the diplomatic practice in third countries (for elaboration, see Bicchi and Maurer, 'European Cooperation Abroad. Introduction to the Special Issue').

${ }^{10}$ Robert D. Behn, 'Why Measure Performance? Different Purposes Require Different Measures', Public Administration Review, vol. 63, no. 5 (2003), pp. 586-606; and Michael Pidd, Measuring the Performance of Public Services: Principles and Practice (Cambridge: Cambridge University Press, 2012).

${ }^{11}$ Paul Sharp, 'For Diplomacy: Representation and the Study of International Relations', International Studies Review, vol. 1, no. 1 (1999), p. 51.

12 Charles Lusthaus, Marie-Helene Adrien, Gary Anderson, Fred Carden and George Plinio Montalvan, Organizational Assessment: A Framework for Improving Performance (Washington, DC: International Development Research Centre, 2002).

${ }^{13}$ Lusthaus et al., Organizational Assessment; Behn, 'Why Measure Performance?'; and Tamar Gutner and Alexander Thompson, 'The Politics of IO Performance: A Framework', The Review of International Organizations, vol. 5, no. 3 (2010), pp. $227-248$.

${ }^{14}$ Knud Erik Jørgensen, Sebastian Oberthür and Jamal Shahin, 'Introduction: Assessing the EU's Performance in International Institutions - Conceptual Framework and Core Findings', Journal of European Integration, vol. 33, no. 6 (2011), p. 604.

${ }^{15}$ Article 221 of the Treaty on the Functioning of the European Union (TFEU).

${ }^{16}$ Ronald P. Barston, Modern Diplomacy (London and New York: Routledge, 4th edition 2013), p. 26.

${ }^{17}$ Sharp, 'For Diplomacy'.

${ }^{18}$ Steffen Bay Rasmussen, 'EU Diplomacy after Lisbon: Institutional Innovation, Diplomatic Practices and International Strategy', Romanian Review of Social Sciences, vol. 7 (2014), pp. 38-73.
} 
Assessing performance in relation to ongoing relevance implies the extent to which an organization meets the needs and requirements of its stakeholders and is able to maintain their continuous support. ${ }^{19}$ Performance in this sense is assessed as the ability of an organization to keep its established goals, programmes and activities in line with the needs of its constituents and stakeholders. To extrapolate this dimension to the EU, relevance is assessed vis-à-vis EU member states themselves and their citizens. Relevance vis-à-vis member states links back to such functions as delegation and cooperation. For the EU as a diplomatic actor, this aspect is especially relevant post-Lisbon, since the EEAS in Brussels links national and EU diplomatic efforts, and expectations are high in relation to cooperation with EU member states on the ground. Cooperation with EU member states can be interpreted as a new and core diplomatic function of a diplomatic representation such as an EU delegation. The Lisbon Treaty entails that EU diplomatic actors, both the EU member states' embassies and the EU delegations in third countries, 'shall cooperate and shall contribute to formulating and implementing the common approach' ${ }^{20}$ The issue of leadership, for which the EU had been criticized pre-Lisbon, is addressed by this function. By assuming the function of the Presidency also in political affairs, by showing strong leadership and through engaging in cooperation, a more strategic approach between the EU and member states' actions on the ground can be assumed.

Finally, organizational management literature talks about resources. ${ }^{21}$ In relation to so-called (diplomatic) 'actorness', scholars discuss the EU's capabilities, ${ }^{22}$ or more specifically 'diplomatic capital' ${ }^{23}$ : the resources and instruments that are used in such a way as to contribute to shared commitments to values; and possessing the ability to identify priorities and formulate actions in a consistent and coherent manner. These resources refer to both the political and social capital (that is, the authority, competences, reputation and power, etc.), which are constantly renewed.$^{24}$ Establishing and maintaining overseas diplomatic offices is not solely linked to one's international identity, but represents an essential resource as a means of communication, source of information and key contact-point for the promotion of interests abroad. The obligations of both national embassies and the EU delegations to 'step up cooperation by exchanging information and carrying out joint statements', as well as to cooperate in 'ensuring that [...] Union positions and actions [...] are complied with and implemented' ${ }^{25}$ rely heavily on communication, a quintessential function for diplomacy. ${ }^{26}$ In both bilateral and multilateral diplomatic relations, communication is omnipresent; the diplomatic community relies on information-gathering, information-negotiating and identifying other actors' intentions, especially in an era of complex international relations. ${ }^{27}$ This dimension implicitly places the emphasis on achieving coherence, a recurrent theme in debating EU affairs. An analysis of capabilities - that is, the EU's ability to use appropriate instruments and techniques to pursue coherent diplomatic presence - is thus central.

The three criteria (effectiveness, relevance and capabilities) are hereafter used in order to examine diplomatic cooperation abroad in Moldova, Ukraine and Belarus. The first empirical section evaluates the effectiveness - in relation to the goals set by the Treaty of Lisbon - of the EU delegations representing the Union and the EU member states' perceptions of this role. The second section discusses relevance in terms of the new cooperation function assumed by the EU delegations and the member states' reaction to it. The third empirical section analyses capabilities through a screening of the different resources.

\footnotetext{
${ }^{19}$ Lusthaus et al., Organizational Assessment.

${ }^{20}$ Consolidated Texts of the EU Treaties as Amended by the Treaty of Lisbon, Article 32.

${ }^{21}$ Performance literature considers the efficiency and financial viability of an organization as important dimensions for analysing performance; see Lusthaus et al., Organizational Assessment.

${ }^{22}$ Michael H. Smith, 'The EU as a Diplomatic Actor in the Post-Lisbon Era: Robust or Rootless Hybrid?', in Joachim Koops and Gjovalin Macaj (eds), The European Union as a Diplomatic Actor (Basingstoke: Palgrave Macmillan, 2015), pp. 11-30; and Charlotte Bretherton and John Vogler, The European Union as a Global Actor (New York, NY: Routledge, 2006).

${ }^{23}$ Rebecca Adler-Nissen, 'The Diplomacy of Opting Out: A Bourdieudian Approach to National Integration Strategies', Journal of Common Market Studies, vol. 46, no. 3 (2008), pp. 663-684.

${ }^{24}$ Adler-Nissen, 'The Diplomacy of Opting Out'.

${ }^{25}$ Consolidated Texts of the EU Treaties as Amended by the Treaty of Lisbon Article 35.

${ }^{26}$ Iver B. Neumann, 'Globalization and Diplomacy', in Andrew F. Cooper, Brian Hocking and William Malev (eds), Global Governance and Diplomacy (Basingstoke: Palgrave Macmillan, 2008), pp. 15-28.

${ }^{27}$ Harold Nicolson, Diplomacy (Washington, DC: Institute for the Study of Diplomacy, $3^{\text {rd }}$ edition 1988); Geoffrey R. Berridge, Diplomacy: Theory and Practice (Basingstoke: Palgrave Macmillan, 5 ${ }^{\text {th }}$ edition 2015); Jean-Robert Leguey-Feilleux, The Dynamics of Diplomacy (Boulder, CO: Lynne Rienner, 2008).
} 


\section{Effectiveness: Is the Union Represented in Belarus, Moldova and Ukraine?}

An overview of the EU's diplomatic network worldwide, represented by both the EU member states' embassies and the EU delegations, shows a rather incremental diplomatic network for the EU, comparable to some of the biggest EU member states: it ranks fourth after France, Germany and the United Kingdom (see Table 1 below).

In both Belarus and Moldova, out of 35 foreign missions, almost half are represented by EU member states and EU diplomatic representations: fifteen in Belarus; and thirteen in Moldova. The diplomatic community is rather small and EU actors play a major role in this community. As one interviewee in Moldova stated: 'we conduct diplomacy on two main levels. One, more concrete, involves dealing with local authorities in the host country and thus developing bilateral relations. And another, a broader one, to create a proper climate and atmosphere to serve peace and development, especially for the younger generations to come'. ${ }^{28}$ In Belarus, given the geopolitical context and the crisis in neighbouring Ukraine, diplomacy is about the 'spreading of national and EU good ideas' within a small group of diplomats 'where everyone knows everyone'. ${ }^{29}$ In Ukraine, on the other hand, out of 155 foreign representations, 26 represent the EU member states and the EU, with only Ireland, Luxembourg and Malta not having a diplomatic representation in Kiev. Here, the diplomatic community is rather large, and EU diplomatic actors have to maintain constant contact, be involved, competitive and very active in order to be heard and seen. According to one interviewee, the conduct of diplomacy becomes 'a skill that helps maintain foreign relations in a supportive, cooperative manner and we are involved in change-related processes and influences in host countries', ${ }^{30}$

Table 1: EU Diplomatic Missions Worldwide and Presence in Belarus, Moldova and Ukraine

\begin{tabular}{|c|c|c|c|c|c|}
\hline \multirow[b]{2}{*}{ Country } & \multirow[b]{2}{*}{$\begin{array}{l}\text { No. of foreign } \\
\text { representations } \\
\text { worldwide }^{31}\end{array}$} & \multirow[b]{2}{*}{$\begin{array}{l}\text { Out of which } \\
\text { total number of } \\
\text { embassies }\end{array}$} & BELARUS & MOLDOVA & UKRAINE \\
\hline & & & \multicolumn{3}{|l|}{ Presence } \\
\hline Austria & 371 & 83 & $\sqrt{ }$ & & $\sqrt{ }$ \\
\hline Belgium & 399 & 93 & & & $\sqrt{ }$ \\
\hline Bulgaria & 143 & 74 & $\sqrt{ }$ & $\sqrt{ }$ & $\sqrt{ }$ \\
\hline Croatia & 140 & 54 & & & $\sqrt{ }$ \\
\hline Cyprus & 158 & 45 & & & $\sqrt{ }$ \\
\hline Czech Republic & 259 & 88 & $\sqrt{ }$ & $\sqrt{ }$ & $\sqrt{ }$ \\
\hline Denmark & 492 & 74 & & & $\sqrt{ }$ \\
\hline Estonia & 196 & 34 & $\sqrt{ }$ & & $\sqrt{ }$ \\
\hline Finland & 438 & 73 & & & $\sqrt{ }$ \\
\hline France & 721 & 165 & $\sqrt{ }$ & $\sqrt{ }$ & $\sqrt{ }$ \\
\hline Germany & 569 & 155 & $\sqrt{ }$ & $\sqrt{ }$ & $\sqrt{ }$ \\
\hline Greece & 268 & 84 & & & $\sqrt{ }$ \\
\hline Hungary & 288 & 77 & $\sqrt{ }$ & $\sqrt{ }$ & $\sqrt{ }$ \\
\hline Ireland & 163 & 58 & & & \\
\hline Italy & 661 & 124 & $\sqrt{ }$ & $\sqrt{ }$ & $\sqrt{ }$ \\
\hline
\end{tabular}

\footnotetext{
${ }^{28}$ Interview with national diplomat, Chisinau (November 2013).

${ }^{29}$ Interview with national diplomat, Minsk (September 2014).

${ }^{30}$ Interview with national diplomat, Kiev (November 2013).

${ }^{31}$ Including consulates, honorary consulates, trade representations and other diplomatic representations (such as offices).
} 


\begin{tabular}{|c|c|c|c|c|c|}
\hline Latvia & 171 & 34 & $\sqrt{ }$ & $\sqrt{ }$ & $\sqrt{ }$ \\
\hline Lithuania & 180 & 39 & $\sqrt{ }$ & $\sqrt{ }$ & $\sqrt{ }$ \\
\hline Luxembourg & 156 & 30 & & & \\
\hline Malta & 180 & 23 & & & \\
\hline Netherlands & 446 & 111 & & & $\sqrt{ }$ \\
\hline Poland & 290 & 89 & $\sqrt{ }$ & $\sqrt{ }$ & $\sqrt{ }$ \\
\hline Portugal & 298 & 71 & & & $\sqrt{ }$ \\
\hline Romania & 310 & 92 & $\sqrt{ }$ & $\sqrt{ }$ & $\sqrt{ }$ \\
\hline Slovakia & 203 & 64 & $\sqrt{ }$ & & $\sqrt{ }$ \\
\hline Slovenia & 111 & 37 & & & $\sqrt{ }$ \\
\hline Spain & 498 & 119 & & & $\sqrt{ }$ \\
\hline Sweden & 441 & 89 & $\sqrt{ }$ & $\sqrt{ }$ & $\sqrt{ }$ \\
\hline $\begin{array}{l}\text { United } \\
\text { Kingdom } \\
\end{array}$ & 432 & 149 & $\sqrt{ }$ & $\sqrt{ }$ & $\sqrt{ }$ \\
\hline $\mathrm{EU}$ & 140 & 140 & $\sqrt{ }$ & $\sqrt{ }$ & $\sqrt{ }$ \\
\hline & \multicolumn{5}{|c|}{$\begin{array}{l}\text { no presence } \\
\text { highest number of embassies } \\
\text { lowest number of embassies }\end{array}$} \\
\hline
\end{tabular}

Source: Data compiled by the author based on the websites of the above embassies, their Ministry of Foreign Affairs, the EEAS, as well as the www.embassypages.com website.

In Belarus, Moldova and Ukraine, the EU delegations have the status of diplomatic missions and are tasked to represent the Union officially in these countries. Opened in Minsk in 2008, in Chisinau in 2005 and in Kiev in 1992, the analytical interest in these countries is precisely because all of them opened before Lisbon, initially as Commission representations. Post-Lisbon, the EU delegations have acquired legal recognition that upgraded the former Commission representations to full-blown Union delegations. The task of representing the EU as a whole that has been given to the EU delegations has been embraced. For diplomats within the EU delegations, the practice of diplomacy is:

[...] the duty to properly represent the interests of the EU citizens, businesses, society and the EU memberstates vis-à-vis our [Ukrainian] counterparts. We have to be able to present them to the public in third countries; to present a proper and unbiased picture of the EU, to explain our [EU] position, to provide the background of what is going on in the EU, what is the position of the EU. ${ }^{32}$

Consequently, the conduct of diplomacy for national diplomats implies representing their own country and a constant exercise to "try to influence the situation in order to reach the foreign policy goals of my country'. ${ }^{33}$ The main division of tasks regarding representation is hence straightforward: the EU delegations represent the EU in areas of exclusive and shared competences, while every member state represents its own interests bilaterally with the host country.

The responsibility for representation and cooperation was taken over by most EU delegations from early $2010 .{ }^{34}$ It appears that embracing this diplomatic function of representation provides continuity and builds diplomatic capacity ${ }^{35}$ - issues that raised concerns pre-Lisbon and were associated with the rotating Presidency. Empirical evidence shows that in Moldova or Ukraine, having the role of the rotating Presidency occupied by a small member state could become a diplomatic disaster, especially if the member

\footnotetext{
${ }^{32}$ Interview with EU diplomat, Kiev (November 2013).

${ }^{33}$ Interview with national diplomat, Chisinau (November 2013).

34 See Council note $17770 / 1 / 09$ on EU diplomatic representation in third counties, available online at http://register.consilium.europa.eu/doc/srv?l=EN\&f=ST\%2017770\%202009\%20REV\%201 .

${ }^{35}$ Interview with EU diplomat, Kiev (June 2016).
} 
state had no previous experience of this role, was under-staffed and was mainly involved in bilateral diplomatic relations. ${ }^{36}$ The extreme negative consequence of this was that it showed the lack of knowledge of smaller member states of the EU context or even the agenda vis-à-vis third countries. ${ }^{37}$ From another perspective, the fact that EU member states, especially newcomers to the EU, will no longer have the opportunity to be in the role of a Presidency is a downturn, in the sense that it is important for local authorities to see that the EU is entrusting this country with playing such a central role: 'in the case of the Lithuanian Presidency, which is post-Lisbon already, as a neighbour, it should play a bigger role in Minsk so that in Brussels it can also promote what is happening on the ground' ${ }^{38}$

Post-Lisbon, abolishing the chairmanship of the EU Presidency in host countries increased the EU's visibility, as the EU delegation represents the EU in all policy areas where the EU has competence. ${ }^{39}$ Whereas it was initially expected that this would be a highly difficult logistical effort for the newly established EU delegations, in practice the level of engagement with the member states' embassies on this matter is relatively high, also because of the Commission representations' previous activity. ${ }^{40}$ Besides, the EU delegations are constantly growing their expertise in representing the EU. Member states' embassies therefore entrust the delegations with the (EU) representation role, while still preserving their watchdog role. ${ }^{41}$ This came with acquiring EU delegation diplomats at the level of Head of Delegations, but also in the Political and Economic sections as well as policy officers, with previous diplomatic experience. ${ }^{42}$ On the ground, there is a lot of synergy and cohesion in relation to the traditional function of diplomacy among the EU delegations and national embassies, including those embassies that have been in host countries since their independence. There is a general openness towards the assumed leading role of the EU delegations, while national embassies are still trying to preserve their own visibility or their autonomous position. Variations in the degree of engagement come with the political culture of the EU member states themselves: countries such as Germany, Sweden or the Netherlands are very outgoing, flexible, straightforward and transparent, which facilitates better cooperation with the EU delegation. Others, such as Poland, Romania, Hungary or Slovakia, are more traditional, engaging in bilateral diplomacy; while others are more secretive in their conduct of diplomacy, including the United Kingdom. ${ }^{43}$ Yet, the EU delegations assess that the diplomatic community is active and engaged, which facilitates open debates on the diversity of issues put forward on the agenda. Moreover, there are some countries among the newest and oldest members that are active in the Eastern neighbourhood; hence they are contributing to shaping a common (EU) position and are therefore committed to the EU delegation representing the EU position. ${ }^{44}$

\section{Relevance vis-à-vis EU Member States: Or What is the 'Common Approach' on the Ground?}

Representing the Union as a political entity through the EU delegations is an important step forward. On the ground, however, the new faces of the old challenges revolve around the new amendments of the Lisbon Treaty regarding formulating and implementing a common approach. For the EU delegations in Belarus, Moldova and Ukraine, the Lisbon Treaty means more work. This new function of cooperation brings more pressure. In Belarus, for example, there are certain expectations from national diplomats regarding this function. Some argue that the EU Delegation in Minsk needs to do more, while others consider the EU Delegation's role to be neutral. ${ }^{45}$ For the EU delegations, this function implies that they need to follow the political discussions all the time and to understand the current state of affairs in host countries. ${ }^{46}$

\footnotetext{
${ }^{36}$ Interview with national diplomat, Kiev (2013); interview with national diplomat, Chisinau (June 2015).

${ }^{37}$ Interview with national diplomat, Kiev (2013); interview with national diplomat, Chisinau (June 2015).

${ }^{38}$ Interview with national diplomat, Minsk (September 2014).

${ }^{39}$ Interview with national diplomat, Minsk (September 2014).

${ }^{40}$ Interview with national diplomat, Chisinau (June 2015); and interview with EU diplomat, Kiev (June 2016).

${ }^{41}$ Interview with EU diplomat, Kiev (June 2016).

${ }^{42}$ Interview with EU diplomat, Kiev (June 2016).

${ }^{43}$ Interview with national diplomats, Kiev (2013).

${ }^{44}$ Interview with national diplomat, Kiev (2013); interview with national diplomat, Minsk (2014); and interview with national diplomat, Chisinau (2015).

${ }^{45}$ Interview with national diplomats, Minsk (September 2014).

${ }^{46}$ Interview with EU diplomats, Chisinau (November 2013); Minsk (2014); and Kiev (2016).
} 
So, have the EU delegations become brokers for a common approach? For the EU Delegation in Kiev, the common approach implies a high degree of cooperation established through constant meetings with the EU member states' embassies, at different levels, as well as an extensive secretarial task of organizing, complementing agendas, note-taking, information-gathering and sharing. For the EU delegations' policy officers, the new function resembles the Council working procedures in Brussels, with the major difference being that, on the ground, there is little room to take immediate actions, as such directives come from Brussels. ${ }^{47}$ The cooperation function quite often becomes the task of acting as the broker of common approaches or common statements. Once a common agreement has been reached on the ground, it is easier to act as one consolidated team vis-à-vis the host country. In this sense, the context matters. For the EU Delegation in Minsk, the common approach is very much about the EU member states that have to implement or respect the modus vivendi designed in Brussels, where policy towards Belarus has been shaped: 'what is decided in Brussels is the Bible'. ${ }^{48}$ As one diplomat explained: 'EU values and policy lines are agreed upon in Brussels. The policy lines are shaped there, including the general understanding that reports come straight to third countries and not necessarily to capitals'. ${ }^{49}$ The common approach is thus about relating to the general political lines established in Brussels and, if this does not happen on the ground, diplomats then revert to Brussels to react and look for common lines. In a different context, in Chisinau, some national diplomats find that what is lacking is cooperation on policy matters. The weakness of Moldova-EU diplomatic relations is then the exercise of lobbying the Moldovan authorities as a common front. ${ }^{50}$ For the EU Delegation in Moldova, the common approach is, in the context of different EU member states' interests, the result of the compromise between a more technical and a more political approach towards the host country. ${ }^{51}$

Creating synergies in cooperation for achieving the common approach is a challenging task for the EU delegation. EU member states benefit differently from common meetings, yet they are not open about it; which makes it difficult for the EU delegation to synthesize the results. Some member states are not cooperative at all and do not come to meetings. This can be for different reasons: from more objective reasons, such as lack of personnel, low or no knowledge of English (the working language of the meetings), to less objective reasons such as not being interested in the issue. Logistically, the EU delegation has to keep every EU member state on board and informed; in practice, this resulted in the EU delegations always creating minutes and the member state using the delegation as a back office. ${ }^{52}$ Thus, acting as a broker for the common approach is not an easy task. It is often rather complicated, especially in those sensitive areas where EU member states have certain interests, whether migration, education, visas, energy or trade. Some (Poland, Romania, Hungary and Slovakia) lobby their delegation strongly; being very active in pushing for their own interests, and as neighbours of the host countries, they feel more confident in their national diplomatic line than in the EU approach. Being so focused on the primacy of their national diplomatic expertise often hampers achieving a common approach and makes these member states act short-sightedly. This, in turn, leaves room for mistakes, such as confusing instances of bilateral track diplomacy with the (EU) multilateral approach. As result, there is little synergy between the national and European diplomacy. According to one diplomat, there is a degree of secrecy in the conduct of diplomacy, such as that of the United Kingdom, which has its own agenda: 'they say something, but then do something else'. ${ }^{53}$ These instances are not uncommon for Poland as well, which prefers to pursue a parallel agenda (especially in Moldova and Ukraine).

As a general rule, however, national embassies regard the cooperation performed by the EU delegations positively. On the one hand, they are free of the logistical burden that came with the rotating Presidency role; on the other hand, they now have, in addition to the instrument of bilateral diplomacy, the European apparatus (to use in achieving their foreign policy goals). EU member states are often subtle in side-stepping from agreed positions, covering this under 'miscommunication'. For instance, in the case of

\footnotetext{
${ }^{47}$ Interviews with EU Delegation policy officers, Kiev (2013).

${ }^{48}$ Interview with EU diplomat, Minsk (September 2014).

${ }^{49}$ Interview with national diplomat, Minsk (September 2014).

${ }^{50}$ Interview with national diplomats, Chisinau (November 2013); and Chisinau (June 2015).

${ }^{51}$ Interview with EU diplomat, Chisinau (November 2013).

${ }^{52}$ Interviews with national and EU diplomats in Kiev (2013); Minsk (2014); and Chisinau (2015).

${ }^{53}$ Interview with national diplomat, Kiev (2013).
} 
former Ukrainian prime minister Yulia Tymoshenko ${ }^{54}$, the common EU position on the ground was that the Council conclusions are the lowest common denominator. Some EU member states chose to go public with statements encouraging the opposite, such as signing the Association Agreement with Ukraine regardless of the Council conclusions; this was a diplomatic statement approved and instructed by their national capitals and in spite of the common agreement established. ${ }^{55}$ In Belarus, side-stepping may actually imply a political and diplomatic deadlock, which EU member states thus tend to avoid. For those EU member states that have been engaged in diplomatic endeavours for a longer amount of time, the common approach is sometimes about even more practical things, such as ensuring that everyone attends events: in a small community, if all or none attend, it is not only visible but may send the wrong message to the host country. ${ }^{56}$

\section{Capabilities: A Screening of Resources in Belarus, Moldova and Ukraine}

Previous research shows the wide and varied typology of the diplomats' communication infrastructure in Moldova and Ukraine (see Table 2 below). These meetings today constitute mechanisms of cooperation, provide a common communication infrastructure and account for some degree of institutionalized practices. Empirical evidence shows that EU diplomatic actors engage in a high degree of information-sharing of written and oral reports, formal and informal data, as well as exchange of personal contacts. As a result, the EU delegations started to play a more central role in becoming an informational network hub. National diplomats believe that these information exchanges should be further regularized and better centralized. ${ }^{57}$

Table 2: Diplomats' Communication Infrastructure in Moldova and Ukraine

\begin{tabular}{|c|c|c|}
\hline Typology & Heading & Frequency \\
\hline \multirow{2}{*}{$\begin{array}{l}\text { Diplomatic } \\
\text { ranking }\end{array}$} & (1) EU-member states & $\begin{array}{l}\text { Moldova: once every two } \\
\text { months } \rightarrow \text { six per year } \\
\text { Ukraine: once per month } \rightarrow 12 \\
\text { per year }\end{array}$ \\
\hline & $\begin{array}{l}\text { (2) Weekly meetings } \\
\text { of Heads of Delegation } \\
\text { (HoDs) }\end{array}$ & $\begin{array}{l}\text { Every week on political issues, } \\
\text { occasionally on civil society } \\
\text { issues (approx. two-three times } \\
\text { per year }\end{array}$ \\
\hline \multirow{3}{*}{ Topic } & $\begin{array}{l}\text { (1) Thematic EU } \\
\text { donor meetings }\end{array}$ & \multirow{3}{*}{ Called based on necessity } \\
\hline & $\begin{array}{l}\text { (2) Consultations with } \\
\text { other EU donors }\end{array}$ & \\
\hline & $\begin{array}{l}\text { (3) Member states' } \\
\text { roundtables }\end{array}$ & \\
\hline $\begin{array}{l}\text { Group } \\
\text { affiliation }\end{array}$ & $\begin{array}{l}\text { (1) EU donor meetings } \\
\text { within regional } \\
\text { frameworks of } \\
\text { cooperation: } \\
\text { Visegrad Group }\end{array}$ & $\begin{array}{l}\text { Varies per country as follows: } \\
\text { Moldova: once per year; }\end{array}$ \\
\hline
\end{tabular}

\footnotetext{
54 former Ukrainian prime minister Yulia Tymoshenko who was sentenced to 7 years in prison after a politically motivated criminal case

${ }^{55}$ Interview with policy officers in the EU Delegation, Kiev (2013).

${ }^{56}$ Interview with national diplomat, Minsk (September 2014).

${ }^{57}$ Interviews with national diplomats, Kiev (November 2013); and Chisinau (November 2013).
} 


\begin{tabular}{|c|c|c|}
\hline & \multirow[b]{2}{*}{$\begin{array}{l}\text { Nordic Plus } \\
\text { group }\end{array}$} & $\begin{array}{l}\text { Ukraine: twice per year } \\
\text { formally, to several times per } \\
\text { year informally }\end{array}$ \\
\hline & & $\begin{array}{l}\text { Moldova: occasionally } \\
\text { Ukraine: twice per year }\end{array}$ \\
\hline \multirow[t]{2}{*}{ Formality } & (1) Formal events & $\begin{array}{l}\text { Organized based on the early } \\
\text { agendas of EU delegations and } \\
\text { member states' embassies; at } \\
\text { least one event per actor }\end{array}$ \\
\hline & (2) Non-formal events & Information not disclosed \\
\hline
\end{tabular}

Source: D. Baltag and M. Smith, 'EU and Member State Diplomacies in Moldova and Ukraine: Examining EU Diplomatic Performance Post-Lisbon’, European Integration Online Papers (Vienna: EIoP, 2015), p. 19.

The legacy of Commission representations and a certain path-dependency is observable in all three countries. On the one hand, the Commission offices were established as information offices and the EU delegations today embrace fully the traditional communication function; on the other hand, the EU delegations have embraced more technical tasks, such as project management, as the Commission offices were established as operational offices. A delegation's activities are therefore divided among operational, administrative, and political and diplomatic issues (see Table 3 below). ${ }^{58}$ Only approximately 10 per cent of the work relates to the main functions of traditional diplomacy such as gathering, synthesizing and producing information, intelligence and counter-intelligence, producing reports and policy advice for headquarters, representing the EU interests through engaging in public diplomacy, or developing economic and commercial cooperation through engaging in trade diplomacy.$^{59}$ Approximately 50 per cent of activity (the Commission legacy) is operational activities or what can be coined as sectoral diplomacy tasks, such as project management in the areas of good governance and democratization, economic cooperation and social and regional development, and infrastructure and environment-related developments. Diplomatic practice nowadays has diversified and expanded to the extent of embracing new functions, such as acting as a donor.

Table 3: Structure of Work in EU Delegations

\footnotetext{
58 The data provided in Table 3 is based on the interviewees' own perception: they evaluated the structure of work of the EU delegation upon reflection of their assignments during the duration of their official posting and provided an estimate.

${ }^{59}$ Interviews with diplomats and policy officers in the EU Delegations in Chisinau and Kiev (November 2013).
} 


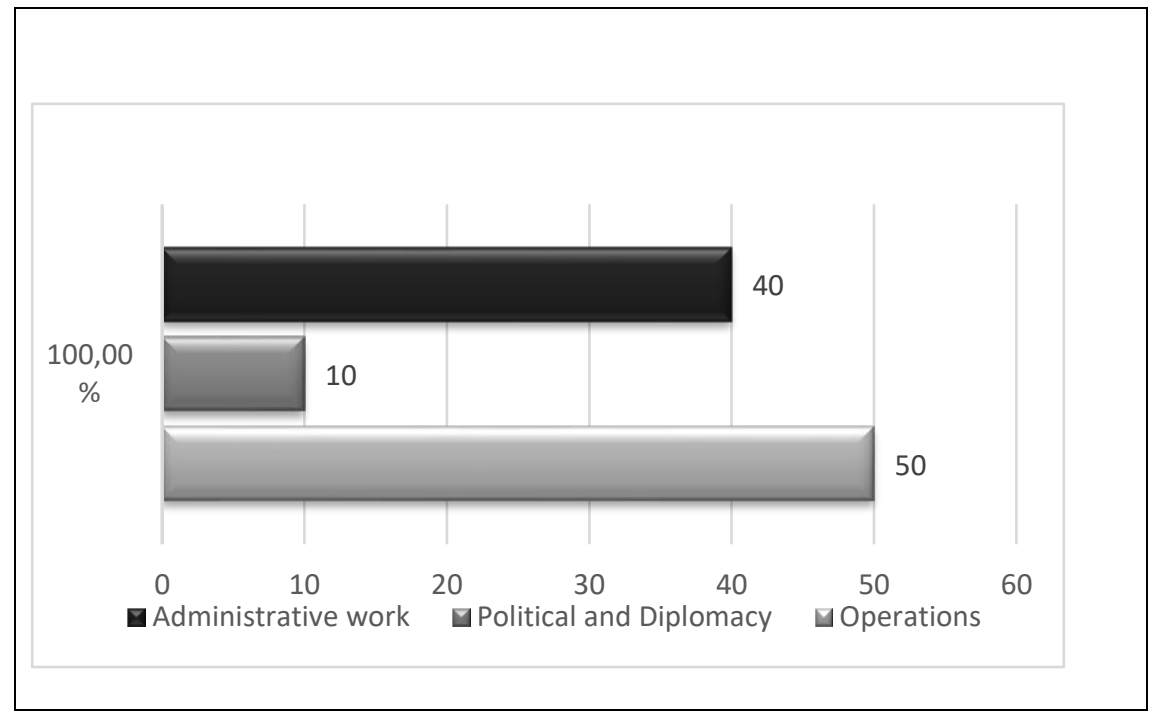

Source: Data compiled by the author based on fieldwork conducted in Moldova and Ukraine, 2013-2015.

Diplomats noted on several occasions that in Eastern Europe the conduct of diplomacy is aid-driven and the EU delegations have bigger operational sections than political units. ${ }^{60}$ Relevant examples here are the EU delegations in Moldova and Ukraine, which were established as Commission representations for more than one year. On a daily basis, both were responsible for EU aid implementation, with little to no coordination with the member states. There have been positive developments post-Lisbon, in the sense that there is now a wide communication infrastructure, coordinated by the EU delegations and open to all EU member states. To a large extent, the communication infrastructure serves as a helpful resource for conducting aid-driven diplomacy. The meetings of EU delegation heads continue today to be mostly used for project coordination and avoid policy coordination discussions. ${ }^{61}$ As a French diplomat in Moldova emphasized, the EU Delegation in Chisinau is relying on a lot of technical aid discussions, which is a bit outside what cooperation between the member states and the EU should entail and 'this is not really how diplomacy functions', ${ }^{6}$

Furthermore, establishing a European esprit de $\operatorname{corps}^{63}$ is an issue that is not uncommon in these countries, just as much as it is in the EEAS. On the ground, having one-third of personnel from the EEAS brings the 'diplomatic' into the work of the EU delegations. Yet these are national diplomats, who are former employees of their ministry of foreign affairs (MFA) and who, after spending four years in the host country, will return not to the EEAS in Brussels but to their national MFA. Whereas technically this might not seem a problem in third countries, the EU delegation staff perceives this as negative: national diplomats find it difficult to detach themselves from their background, so they preach national diplomacy instead of European diplomacy and follow national interests. ${ }^{64}$ Another issue is the hiring of local staff who, unlike their supervisors, speak the local language. Usually Commission personnel do not have a requirement to speak the local language. Yet since reports from the operations section bypass the EEAS staff, with the exception of the HoD, these reports might carry an indirect political message vis-à-vis the host country. ${ }^{65}$ For example, EEAS staff in the EU delegations are often surprised to read about the positive developments regarding reforms carried out by certain ministries in host countries. Such a technical report may therefore tailor a political message of approval to those ministries, which, according to political officers in the EU

\footnotetext{
${ }^{60}$ Interviews with national diplomats, Kiev (November 2013); and Chisinau (November 2013 and 2015).

${ }^{61}$ Interviews with EU diplomat, Minsk (September 2014); and national diplomat, Chisinau (2015).

${ }^{62}$ Interview with national diplomat, Chisinau (June 2015).

${ }^{63}$ Karolina Pomorska and Ana E. Juncos, 'In the Face of Adversity: Explaining the Attitudes of EEAS Officials vis-à-vis the New Service', Journal of European Public Policy, vol. 20, no. 9 (2013), pp. 1332-1349.

${ }^{64}$ Interviews with policy officers and Operations officers in the EU Delegations in Chisinau and Kiev (November 2013).

${ }^{65}$ Interview with EU diplomat, Kiev (November 2013).
} 
delegations, is an indirect message of political support; and this is not necessarily aligned with the EU's political position in Brussels vis-à-vis the country. ${ }^{66}$ EEAS staff in the EU delegations have the possibility to see the mentioned reports a couple of days before they are published, but since these are already approved in Brussels, this is merely for informational purposes.

As a general observation, human resource issues are recurrent for both the national and Union diplomatic representations: for example, being understaffed; not sufficiently trained in EU policy-making; understanding, or not, the language of the host country; as well as overlapping national backgrounds. For national embassies, the issue of esprit de corps is mainly linked to most embassies being understaffed. Most embassies are small, with only two or three diplomats. Diplomats argue that in Eastern Europe the size of the mission makes a difference: 'in Moscow, for example, most embassies are very well staffed, yet having a smaller embassy here makes us work together more often and coordinate better' ${ }^{67}$ Another factor when it comes to human resources is the age range, experience accumulated of all participants and their language skills: being a skilful diplomat and knowing at least Russian is extremely important in all three countries. Personal charm and personality matter just as much: 'it is about the people, to be friendly and understanding; in other cases (working in Central Asia), you have to be more convincing and then the diplomatic activity is tenser' ${ }^{68}$ Having linkages with one region or another, or historical ties, may have negative repercussions on the conduct of diplomacy of certain EU member states and heads of EU delegations in Ukraine, Belarus or Moldova, as they become hostage of their own past and do not account for the broader European perspective. The use of European diplomacy in the benefit of the national diplomatic interest (such as having a Polish ambassador in Ukraine, or a Latvian ambassador in Belarus) often exhibits the pursuit of national interests and overshadows the European interests. ${ }^{69}$

In all three countries, an institutional issue echoes Brussels inter-institutional dynamics: internally, the EU delegations reflect the tensions between the European Commission and the EEAS in Brussels. Structurally, there are two parts within the EU delegations: the Commission part, represented by the Directorate-General for International Cooperation and Development (DG DevCo) and the DG Trade personnel $;{ }^{70}$ and the EEAS part, represented by national diplomats. This is a huge logistical challenge. The European Commission's staff work on sensitive issues in the area of good governance, rule of law, education, corruption and energy, etc., which are all very political in nature. The EEAS personnel are in charge of the political agenda, yet they are most often not consulted on the reports on sectoral issues that go directly to Brussels, bypassing the political officers. Within each EU delegation there is a public procurement office, which is also staffed by Commission personnel. The EEAS did not have its own budget until 2011, and the Commission refused to provide professional advice to the EEAS personnel within the EU delegations. EU delegation staff had to learn the basics of running public tenders and writing contracts, which is not part of the job description of a political officer. ${ }^{71}$ As a result, EU diplomacy is in practice split by dividing walls: 'in Minsk, the Delegation works in close cooperation because it is a small team of young people; however, this does not remove administrative barriers' ${ }^{72}$

\section{Conclusion}

This concise analysis of European diplomatic cooperation among EU delegations and national embassies in Belarus, Moldova and Ukraine has uncovered the nature of the practice of European cooperation abroad. On the ground, the context of the diplomatic practices is that the EU and national levels coexist and continue to engage in diplomatic activities. Thus, the Lisbon innovations and the change to full-fledged EU delegations do not substitute national diplomacy, but instead enhance the practices within European

\footnotetext{
${ }^{66}$ Interview with policy officers, Kiev (November 2013).

${ }^{67}$ Interview with national diplomat, Minsk (September 2014).

${ }^{68}$ Interview with national diplomat, Minsk (September 2014).

${ }^{69}$ Interview with national diplomats and policy officers in the EU Delegations in Kiev (November 2013); and Minsk (September 2014).

${ }^{70}$ Until recently (2015), the EU Delegation in Chisinau did not have a trade officer and the EU Delegation in Belarus still does not have one.

${ }^{71}$ Interview with policy officer in the EU Delegation, Kiev (November 2013).

${ }^{72}$ Interview with EU diplomat, Minsk (September 2014).
} 
diplomatic cooperation abroad. First, the issues of EU visibility and EU diplomatic complexity are reduced. By subsuming the role of the rotating Presidencies, the EU delegations became central actors in representation, but also became communication hubs on the ground and took the lead on cooperation with the EU member states' embassies. Yet post-Lisbon developments also come with certain challenges in identifying a common approach. For some national counterparts, there is an expectation that European cooperation abroad will become more political in nature. National diplomats observe that the high degree of information-sharing and networking becomes more technical in nature, focusing on aid-driven issues rather than identifying issues for lobbying in the relationship with local authorities. While being obliged to cooperate on the ground, diplomatic practice shows that the current coexistence of national and EU diplomacy opts out of the common approach in favour of parallel actions by the individual EU member states. Hence, EU leadership on the ground remains under question, coupled with the lack of direction in relation to a strategic approach between the EU and its member states. Furthermore, the current interinstitutional dynamics within the EU delegations are challenges that have not necessarily emerged postLisbon, but that were also present on the ground earlier. In all three countries, the EU delegations embrace such traditional diplomatic functions as representation and communication, as well as new diplomatic functions such as cooperation with EU member states. One interesting observation is that cooperation in practice implies that the EU delegation continues to conduct aid-driven diplomacy, as a legacy from former Commission representations. It is obvious that on the ground, the practices of European cooperation rely on a developing diplomatic capital, on which diplomatic interaction depends. On the background of accumulating capital without addressing its flaws, it is questionable whether such accumulated capital enables the EU to pursue a coherent diplomatic presence. Against this background, future research should scrutinize further whether the post-Lisbon changes and the EU system of diplomacy are 'fit for purpose'.

Dorina Baltag teaches European Studies at Maastricht University and is a Ph.D. candidate at Loughborough University. She obtained a Marie Curie Fellowship in 2012 (Initial Training Network INCOOP: Dynamics of Inter-institutional Cooperation in the EU) for her current research on EU diplomatic performance in Eastern Europe with a focus on Moldova, Ukraine and Belarus. She contributed to the Routledge Handbook on the European Neighbourhood Policy (Oxford: Routledge, 2017); to External Governance as Security Community Building (London: Palgrave, 2016); and co-edited a special issue of East European Politics on 'Assessing the Performance of the European Union in Central and Eastern Europe and in its Neighbourhood'. Her work has also been published in working papers of the SWP (German Institute for International and Security Affairs, 2011) and NUPI (Norwegian Institute of International Affairs, 2014), INCOOP policy briefs (2013) and EIoP papers (European Integration Online) (2015). 